\title{
Analisis Yuridis Bahaya Narkotika bagi Kesehatan Masa Depan Generasi Muda
}

\author{
Nasrianti ${ }^{1}$, Muhibuddin ${ }^{2}$ \\ Dosen Fakultas Hukum Universitas Malikussaleh
}

\begin{abstract}
Abuse of Narcotics among the younger generation which can damage health and destroy the future of the younger generation and also the continuation of the future of the State then in legal considerations the birth of Law of the Republic of Indonesia Number 35 of 2009 concerning Narcotics is, to create a prosperous, just and prosperous Indonesian society that is evenly material and spiritual based on Pancasila and the 1945 Constitution of the Republic of Indonesia, the quality of Indonesia's human resources as one of the assets for national development needs to be continuously maintained and improved, including the degree of health; Therefore, to improve the health status of Indonesian human resources in the context of realizing the welfare of the people, it is necessary to make efforts to improve in the field of treatment and health services, among others by seeking the availability of certain types of Narcotics which are urgently needed as drugs and to prevent and eradicate the dangers of abuse and illicit Narcotics trafficking and Narcotics Precursor. The method used in this research is a qualitative normative juridical research method, namely a research method that refers to the legal norms contained in legislation. The conclusion of Articles 18 and 19 of Law of the Republic of Indonesia Number 36 of 2009 concerning Health, states that the Government is responsible for empowering and encouraging the active role of the community in all forms of health efforts, and the Government is responsible for the availability of all forms of quality, safe health efforts. efficient, and affordable.
\end{abstract}

Keywords: Narcotics, Health, Future, Generation, Youth

\section{Abstrak}

Penyalahgunaan Narkotika di kalangan generasi muda yang dapat merusakkan kesehatan dan menghacurkan masa depan generasi mudan dan juga kelanjutan masa depan Negara, maka dalam pertimbangan Hukum lahirnya Undang-Undang Republik Indonesia Nomor 35 Tahun 2009 tentang Narkotika adalah, maka untuk mewujudkan masyarakat Indonesia yang sejahtera, adil dan makmur yang merata materiil dan spiritual berdasarkan Pancasila dan Undang-Undang Dasar Negara Republik Indonesia Tahun 1945, kualitas sumber daya manusia Indonesia sebagai salah satu modal pembangunan nasional perlu dipelihara dan ditingkatkan secara terus-menerus, termasuk derajat kesehatannya; karenanya untuk meningkatkan derajat kesehatan sumber daya manusia Indonesia dalam rangka mewujudkan kesejahteraan rakyat perlu dilakukan upaya peningkatan di bidang pengobatan dan pelayanan kesehatan, antara lain dengan mengusahakan ketersediaan Narkotika jenis tertentu yang sangat dibutuhkan sebagai obat serta melakukan pencegahan dan pemberantasan bahaya penyalahgunaan dan peredaran gelap Narkotika dan Prekursor Narkotika. Metode yang digunakan dalam penelitian ini adalah metode penelitian yuridis normatif yang bersifat kualitatif, yaitu metode penelitian yang mengacu pada norma-norma hukum yang terdapat dalam perundang-undangan. Kesimpulan Pasal 18 dan 19 Undang-Undang Republik Indonesia Nomor 36 Tahun 2009 tentang Kesehatan, menyebutkan, bahwa Pemerintah bertanggung jawab memberdayakan dan mendorong peran aktif masyarakat dalam segala bentuk upaya kesehatan.

Kata Kunci:

Bahaya Narkotika, Kesehatan, Masa Depan, Generasi, Muda 


\section{A. PENDAHULUAN}

Persoalan besar di Indonesia sekarang ini adalah semakin maraknya peredaran dan penyalahgunaan narkotika. Peredaran narkotika tersebut kian hebat hingga dapat dikategorikan menjadi sebuah bencana. Dikatakan bencana karena memang peredarannya meningkat setiap tahun dan angka kematian akibat narkotika juga mengalami peningkatan. Penggunanya pun tidak sedikit, dari kalangan remaja, dewasa dan sampai lapisan atas hingga masyarakat lapisan bawah. Untuk menekan terjadi penyalahgunaan narkotika di kalangan generasi muda yang dapat merusakkan kesehatan dan menghacurkan masa depan generasi mudan dan juga kelanjutan masa depan Negara (Zulfa, 2015).

$$
\text { Karenanya pertimbangan }
$$

Hukum lahirnya Undang-Undang Republik Indonesia Nomor 35 Tahun 2009 tentang Narkotika menyebutkan, bahwa untuk mewujudkan masyarakat Indonesia yang sejahtera, adil dan makmur yang merata materiil dan spiritual berdasarkan Pancasila dan UndangUndang Dasar Negara Republik Indonesia Tahun 1945, kualitas sumber daya manusia Indonesia sebagai salah satu modal pembangunan nasional perlu dipelihara dan ditingkatkan secara terus-menerus, termasuk derajat kesehatannya. Oleh karenanya untuk meningkatkan derajat kesehatan sumber daya manusia Indonesia dalam rangka mewujudkan kesejahteraan rakyat perlu dilakukan upaya peningkatan di bidang pengobatan dan pelayanan kesehatan, antara lain dengan mengusahakan ketersediaan Narkotika jenis tertentu yang sangat dibutuhkan sebagai obat serta melakukan pencegahan dan pemberantasan bahaya penyalahgunaan dan peredaran gelap Narkotika dan Prekursor Narkotika.

Sedangkan di satu sisi merupakan obat atau bahan yang bermanfaat di bidang pengobatan atau pelayanan kesehatan dan pengembangan ilmu pengetahuan dan di sisi lain, dapat pula menimbulkan ketergantungan yang sangat merugikan apabila disalahgunakan atau digunakan tanpa pengendalian dan pengawasan yang ketat dan saksama. Untuk itu Pemerintah harus melakukan pengawasan yang ketat terhadap penyalahgunna Narkotika yang terjadi pada saat ini, dan penyalahgunaan Narkotika 
kebanyakan yang dilakukan oleh kalangan anak muda sangat tinggi dan sudah samapai pada taraf membahayakan masa depanya, maka Pemerintah untuk mengatasinya melakukan perubahan terhadap peraturan yang sudah ada, karena beranggapan peraturan sebelumnya belum bisa mengatur dan mengpidanakan para pengguna Narkotika karena jenis Narkotika yang terus berkembang dan lahir bermacam jenis dan model narkotika.

Untuk itu Pemerintah punya kewajiban untuk mejamain keselamatan dan menjaga kesehatan masyarakatnya sebagai mana diatur dalam Pasal 18 dan 19 UndangUndang Republik Indonesia Nomor 36 Tahun 2009 tentang Kesehatan, menyebutkan bahwa Pemerintah bertanggung jawab memberdayakan dan mendorong peran aktif masyarakat dalam segala bentuk upaya kesehatan, dan Pemerintah bertanggung jawab atas ketersediaan segala bentuk upaya kesehatan yang bermutu, aman, efisien, dan terjangkau. Menjamin dan perlindungan terhadap kesehatan masyarakatnya dari bahaya penyalahgunaan Narkotika maka pemerintah telah melakukan langkah- langkah antisipasi dengan melakukan beberapa kali perubahan terhadap Peraturan Menteri Kesahatan Nomor 44 Tahun 2019 tentang Perubahan Penggolongan Narkotika, menyebutkan dalam pertimbangannya, bahwa narkotika merupakan obat atau bahan yang bermanfaat di bidang pengobatan atau pelayanan kesehatan dan pengembangan ilmu pengetahuan, tetapi dapat juga menimbulkan ketergantungan yang sangat merugikan apabila disalahgunakan atau digunakan tanpa pengendalian dan pengawasan yang ketat dan saksama, bahwa terdapat zat psikoaktif baru (new psychoactive substance) yang berpotensi penyalahgunaan dan membahayakan kesehatan masyarakat yang belum termasuk dalam golongan narkotika sebagaimana diatur dalam Lampiran I Undang-Undang Nomor 35 Tahun 2009 tentang Narkotika dan Peraturan lainnya.

Berdasarkan latarbelakang masalah tersebut diatas, maka penulis ingin mengkaji lebih lanjut dengan Judul "Analisis Yuridis Bahaya Narkotika Bagi Kesehatan Masa Depan Generasi Muda”. 


\section{B. PERMASALAHAN}

Berdasarkan uraian di atas, tujuan yang ingin di capai dalam pengkajian penelitian ini adalah untuk mengetahui Analisis Yuridis Bahaya Narkotika Bagi Kesehatan Masa Depan Generasi Muda.

\section{METODE PENELITIAN}

Metode pendekatan yang digunakan dalam penelitian ini adalah pendekatan yang bersifat yuridis normatif, yaitu suatu pendekatan yang secara deduktif menganalisa pasal-pasal dalam perundangundangan pidana positif khususnya dalam KUHP dan Pasal-pasal dalam Perundang-undangan pidana positif di luar KUHP.

\section{PEMBAHASAN}

\section{(1) Analisis Yuridis Bahaya Narkotika Bagi Kesehatan Masa Depan Generasi Muda}

Narkotika merupakan zat atau obat yang sangat bermanfaat dan diperlukan untuk pengobatan penyakit tertentu. Namun, jika disalahgunakan atau digunakan tidak sesuai dengan standar pengobatan dapat menimbulkan akibat yang sangat merugikan bagi perseorangan atau masyarakat khususnya generasi muda. Hal ini akan lebih merugikan jika disertai dengan penyalahgunaan dan peredaran gelap Narkotika yang dapat mengakibatkan bahaya yang lebih besar bagi kehidupan dan nilainilai budaya bangsa yang pada akhirnya akan dapat melemahkan ketahanan nasional. Sedangkan menurut WHO Narkoba adalah semua zat padat, cair maupun gas yang dimaksudkan kedalam tubuh yang dapat merubah fungsi dan struktur tubuh secara fisik maupun psikis tidak termsuk makanan, air dan oksigen dimana dibutuhkan untuk mempertahankan fungsi tubuh normal.

\begin{tabular}{lcr}
\multicolumn{1}{c}{ Demi } & mencegah & dan \\
memberantas & penyalahgunaan & dan \\
peredaran & gelap Narkotika & yang \\
sangat & merugikan & dan
\end{tabular}
membahayakan kehidupan masyarakat, bangsa, dan Negara. Pada Sidang Umum Majelis Permusyawaratan Rakyat Republik Indonesia Tahun 2002 melalui Ketetapan Majelis Permusyawaratan Rakyat Republik Indonesia Nomor VI/MPR/2002 telah merekomendasikan kepada Dewan Perwakilan Rakyat Republik Indonesia dan Presiden Republik Indonesia untuk melakukan perubahan atas Undang-Undang 
Nomor 22 Tahun 1997 tentang Narkotika. maka di keluarkan Undang-Undang Nomor 35 Tahun 2009 tentang Narkotika sebagai pengantinya, karena UU lama sudah tidak sesuai lagi dengan kemajuan zaman dan teknologi. Sehingga narkotika begitu bebas beredar dalam masyarakat secara luas dan dapat di akses dengan mudah untuk di miliki oleh semua kalangan muda sampai kalangan orang tua yang sangat memprihatinkan dan merusak kesehatan masyarakat dan generasi muda sebagai penerus bangsa.

Pemerintah dengan berbagai cara melakukan terobosan untuk melindungi rakyatnya dari kehancuran masa depan generasi mudanya untuk memajukan Pembangunan Nasional, namun banyak kendala yang harus dihadapi oleh Pemerintah baik itu hambatana yang timbul dalam negeri dan maupun pengaruh negatif dari luar negeri. Namun sebagian besar pengaruh yang dialami oleh generasi muda di Era Globalisasi ini datang dari berbagai kelas dan strata sosial. Pengaruh-pengaruh negatif yang menyerang generasi muda di Indonesia tersebut terutama masalah peredaran gelap dan penyalahgunaan narkotika yang dapat menghancurkan generasi penerus cita-cita Pembangunan Nasional. (Heriadi, 2005)

Undang-Undang Nomor 35

Tahun 2009 tentang Narkotika menyebutkan, bahwa tindak pidana Narkotika telah bersifat transnasional yang dilakukan dengan menggunakan modus operandi yang tinggi, teknologi canggih, didukung oleh jaringan organisasi yang luas, dan sudah banyak menimbulkan korban, terutama di kalangan generasi muda bangsa yang sangat membahayakan kehidupan masyarakat, bangsa, dan Negara. Sehingga Undang-Undang Nomor 22 Tahun 1997 tentang Narkotika sudah tidak sesuai lagi dengan perkembangan situasi dan kondisi yang berkembang untuk menanggulangi dan memberantas tindak pidana tersebut, dan selanjutnya dilakukan perubahan jenis-jenis narkotika sesuai dengan kemajuan zaman dengan Peraturan Menteri Kesahatan Nomor 44 Tahun 2019 tentang Perubahan Penggolongan Narkotika, dengan pertimbangannya terdapat zat psikoaktif baru (new psychoactive substance) yang berpotensi penyalahgunaan dan membahayakan 
kesehatan masyarakat yang belum termasuk dalam golongan narkotika sebagaimana diatur dalam Lampiran I Undang-Undang Nomor 35 Tahun 2009 tentang Narkotika dan Peraturan Menteri Kesehatan Nomor 50 Tahun 2018 tentang Perubahan Penggolongan Narkotika.

Daftar narkotika golongan I, golongan II dan golongan III berdasarkan Peraturan Menteri Kesahatan Nomor 44 Tahun 2019 tentang Perubahan Penggolongan Narkotika sebagai berikut.

1. Tanaman Papaver Somniferum $L$ dan semua bagian-bagiannya termasuk buah dan jeraminya, kecuali bijinya.

2. Opium mentah, yaitu getah yang membeku sendiri, diperoleh dari buah tanaman Papaver Somniferum $L$ dengan atau tanpa mengalami pengolahan sekedarnya untuk pembungkus dan pengangkutan tanpa memperhatikan kadar morfinnya.

3. Opium masak terdiri dari: a. candu, hasil yang diperoleh dari opium mentah melalui suatu rentetan pengolahan khususnya dengan pelarutan, pemanasan dan peragian dengan atau tanpa penambahan bahan-bahan lain, dengan maksud mengubahnya menjadi suatu ekstrak yang cocok untuk pemadatan.

b. jicing, sisa-sisa dari candu setelah dihisap, tanpa memperhatikan apakah candu itu dicampur dengan daun atau bahan lain.

c. jicingko, hasil yang diperoleh dari pengolahan jicing.

4. Tanaman koka, tanaman dari semua genus Erythroxylon dari keluarga Erythroxylaceae termasuk buah dan bijinya.

5. Daun koka, daun yang belum atau sudah dikeringkan atau dalam bentuk serbuk dari semua tanaman genus Erythroxylon dari keluarga Erythroxylaceae yang menghasilkan kokain secara langsung atau melalui perubahan kimia.

6. Kokain mentah, semua hasilhasil yang diperoleh dari daun koka yang dapat diolah secara langsung untuk mendapatkan kokaina.

7. Kokaina, metil ester-1-bensoil ekgonina.

8. Tanaman ganja, semua tanaman genus genus cannabis dan semua bagian dari tanaman termasuk biji, buah, jerami, hasil olahan tanaman ganja atau bagian 
tanaman ganja termasuk damar ganja dan hasis.

9. Tetrahydrocannabinol, dan semua isomer serta semua bentuk stereo kimianya.

10. Delta 9 tetrahydrocannabinol, dan semua bentuk stereo kimianya, dan seterusnya.

\section{Sedangkan Narkotikan}

Golongan II ada 91 jenis, dan Narkotikan Golongan III ada 15 jenis

Narkotika, berdasarkan pengolongan jenis narkoka tersebut, menandakan perkembangan lahirnya bermacam jenis Narkotika baru sangat cepat dan sangat membahayakan kesehatan genera muda dan menghancurkan generasi masadepan bangsa Indonesia, sebenarnya Narkotika apabila dikaji dari bidang kesehatan, merupakan salah satu obat yang berkhasiat serta sangat bermanfaat dan sebagai obat yang sangat dibutuhkan bagi kepentingan kesehatan umat manusia untuk kepentingan pengobatan atau pelayanan kesehatan dalam pelaksanaan pembiusan untuk kepentingan operasi untuk menghilangkan rasa sakit dan untuk kepentingan pengobatan kesehatan lainn yang penting penggunaaanya sesuai dengan ketentuan dosis yang dianjurkan dokter, sehingga dalam penggunaan Narkotika tidak menyebabkan dan menjerumuskan generasi muda dalam negatif dan menyebabkan ketergantungan pada Narkotika yang dapat mengganggu kesehatan serta lama kelamaan menjadi gila.

\section{(2) Kesehatan Masa Depan Generasi Muda}

Kesehatan adalah keadaan sehat, baik secara fisik, mental, spritual maupun sosial yang memungkinkan setiap orang untuk hidup produktif secara sosial dan ekonomis. Maka sudah saatnya kita melihat persoalan kesehatan sebagai suatu faktor utama dan investasi berharga yang pelaksanaannya didasarkan pada sebuah paradigma baru yang biasa dikenal dengan paradigma sehat, yakni paradigma kesehatan yang mengutamakan upaya promotif dan preventif tanpa mengabaikan kuratif dan rehabilitatif.

$$
\text { Dalam upaya menjaga }
$$
kesehatan masyarakat dan generasi mudanya Pemerintah punya kewajiban berperan lebih aktih dan menjamin tersedianya fasilitas untuk kesahatan masyarakatnya sebagai mana di amanatkan dalam Pasal 1 UU 
No. 36 Tahun 2009 tentang

Kesehatan, sebagai berikut;

1. Sumber daya di bidang kesehatan adalah segala bentuk dana, tenaga, perbekalan kesehatan, sediaan farmasi dan alat kesehatan serta fasilitas pelayanan kesehatan dan teknologi yang dimanfaatkan untuk menyelenggarakan upaya kesehatan yang dilakukan oleh Pemerintah, pemerintah daerah, dan/atau masyarakat.

2. Perbekalan kesehatan adalah semua bahan dan peralatan yang diperlukan untuk menyelenggarakan upaya kesehatan.

3. Sediaan farmasi adalah obat, bahan obat, obat tradisional, dan kosmetika.

4. Alat kesehatan adalah instrumen, aparatus, mesin dan/atau implan yang tidak mengandung obat yang digunakan untuk mencegah, mendiagnosis, menyembuhkan dan meringankan penyakit, merawat orang sakit, memulihkan kesehatan pada manusia, dan/atau membentuk struktur dan memperbaiki fungsi tubuh.

5. Tenaga kesehatan adalah setiap orang yang mengabdikan diri dalam bidang kesehatan serta memiliki pengetahuan dan/atau keterampilan melalui pendidikan di bidang kesehatan yang untuk jenis tertentu memerlukan kewenangan untuk melakukan upaya kesehatan.

6. Fasilitas pelayanan kesehatan adalah suatu alat dan/atau tempat yang digunakan untuk menyelenggarakan upaya pelayanan kesehatan, baik promotif, preventif, kuratif maupun rehabilitatif yang dilakukan oleh Pemerintah, pemerintah daerah, dan/atau masyarakat.

7. Obat adalah bahan atau paduan bahan, termasuk produk biologi yang digunakan untuk mempengaruhi atau menyelidiki sistem fisiologi atau keadaan patologi dalam rangka penetapan diagnosis, pencegahan, penyembuhan, pemulihan, peningkatan kesehatan dan kontrasepsi, untuk manusia.

8. Teknologi kesehatan adalah segala bentuk alat dan/atau metode yang ditujukan untuk membantu menegakkan diagnosa, pencegahan, dan penanganan permasalahan kesehatan manusia.

9. Upaya kesehatan adalah setiap kegiatan dan/atau serangkaian kegiatan yang dilakukan secara terpadu, terintegrasi dan berkesinambungan untuk memelihara dan meningkatkan derajat kesehatan masyarakat dalam bentuk pencegahan penyakit, peningkatan kesehatan, pengobatan penyakit, dan pemulihan kesehatan oleh pemerintah dan/atau masyarakat.

10. Pelayanan kesehatan promotif adalah suatu kegiatan dan/atau serangkaian kegiatan pelayanan kesehatan yang lebih mengutamakan kegiatan yang bersifat promosi kesehatan.

11. Pelayanan kesehatan preventif adalah suatu kegiatan pencegahan terhadap suatu masalah kesehatan/penyakit.

12. Pelayanan kesehatan kuratif adalah suatu kegiatan dan/atau serangkaian kegiatan pengobatan yang ditujukan untuk penyembuhan penyakit, pengurangan penderitaan akibat 
penyakit, pengendalian penyakit, atau pengendalian kecacatan agar kualitas penderita dapat terjaga seoptimal mungkin.

13. Pelayanan kesehatan rehabilitatif adalah kegiatan dan/atau serangkaian kegiatan untuk mengembalikan bekas penderita ke dalam masyarakat sehingga dapat berfungsi lagi sebagai anggota masyarakat yang berguna untuk dirinya dan masyarakat semaksimal mungkin sesuai dengan kemampuannya.

\section{Dengan demikian Pemerintah}

punya kewajiban untuk melakukan pencegahan terhadap

Penyalahgunaan narkotika dan obatobatan terlarang di kalangan generasi muda dewasa ini kian meningkat dan sangat memprihantikan. Karena di era globalisai sekarang ini semakin maraknya penyimpangan perilaku penyalahgunaan narkoba dikalangan generasi muda tersebut dapat membahayakan keberlangsungan hidup bangsa ini di kemudian hari. Karena pemuda sebagai generasi yang diharapkan menjadi penerus bangsa, semakin hari semakin rapuh digerogoti oleh zat-zat adiktif yang dapat menghancurkan syaraf generasi muda. Sehingga generasi muda tidak dapat berpikir secara jernih. mengakibatkannya generasi muda sebagai harapan bangsa yang tangguh dan cerdas hanya akan tinggal kenangan. Karenanya Pemerintah, Pemerintahan Daerah, Organisasi Masyarakat serta tokoh masyarakat serta orang Tua wajib menjaga dan mengawasi keluarganya dan harus ikut serta dalam pencegahan terjadi penyalahgunaan Narkoba di kalangan generasi muda di masa sekarang ini.

$\begin{array}{rcr}\text { Bahaya } & \text { dan } & \text { dampak } \\ \text { penyalagunaan } & \text { Narkoba } & \text { dalam }\end{array}$ kehidupan masyarakat dan generasi muda sekarang ini dapat menyebabkan beberapa efek bagi kesehatannya sebagai berikut; (Mellisa, 2014)

a. Menurut Efeknya;

1. menimbulkan Halusinogen (halusinasi),

2. Stimulan (seorang pengguna lebih senang dan gembira untuk sementara waktu),

3. Depresan ( tidak sadarkan diri),

4. Adiktif (kecanduan berat).

b. Menurut Jenisnya;

Menimbulkan depresi berat dan bisa gila, apatis, rasa lelah berlebihan, malas bergerak, banyak tidur, gugup, gelisah, selalu merasa curiga, denyut jantung bertambah cepat, rasa gembira berlebihan, banyak bicara namun tidak terarah dan tidak jelas, 
rasa harga diri meningkat, kejangkejang, pupil mata mengecil, tekanan darah meningkat, berkeringat dingin, mual hingga muntah, luka pada sekat rongga hidung, kehilangan nafsu makan, turunnya berat badan.

c. Dampak negatif

Penyalahgunaan

narkoba terhadap anak atau remaja adalah sebagai berikut:

1. Perubahan dalam sikap, perangai dan kepribadian,

2. Sering membolos, menurunnya kedisiplinan dan nilai-nilai pelajaran,

3. Menjadi mudah tersinggung dan cepat marah,

4. Sering menguap, mengantuk, dan malas,

5. Tidak memedulikan kesehatan diri.

6. Suka mencuri untuk membeli narkoba.

Dapat terjadi juga alasan-alasan penyalahgunaan Narkoba oleh pelaku sebagai berikut:

1. Coba - coba : rasa ingin tahu

2. Pengobatan

3. Tekanan lingkungan : ingin diterima kelompoknya

4. ingin diakui oleh teman)

5. Tuntutan pekerjaan

6. Budaya
7. Adiksi /ketergantungan Karenanya dampak penyalahgunaan Narkoba sangat fatal dan dapat merusak masa depan manusia dan masa depan generasi muda yang akan datang, maka untuk menyalamatkan generasi muda dari penyalahgunaan narkoba, pemerintah mengeluarkan peraturan perundangngan yang mengatur tatacara pecegahan baik secara preventif maupun secara refresif atau penegakan hukum untuk memberikan efek jera pada para penyalahgunaan narkoba dan obat-obatan yang tidak sesuai dengan petunjuk dokter, sebagaiimana diatur dalam UndangUndang Nomor 35 Tahun 2009 tentang Narkotika sebagai berikut;

Pasal 111

(1) Setiap orang yang tanpa hak atau melawan hukum menanam, memelihara, memiliki, menyimpan, menguasai, atau menyediakan Narkotika Golongan I dalam bentuk tanaman, dipidana dengan pidana penjara paling singkat 4 (empat) tahun dan paling lama 12 (dua belas) tahun dan pidana denda paling sedikit Rp800.000.000,00 (delapan ratus juta rupiah) dan paling banyak Rp8.000.000.000,00 (delapan miliar rupiah).

(2) Dalam hal perbuatan menanam, memelihara, memiliki, menyimpan, menguasai, atau menyediakan Narkotika 
Golongan I dalam bentuk tanaman sebagaimana dimaksud pada ayat (1) beratnya melebihi 1 (satu) kilogram atau melebihi 5 (lima) batang pohon, pelaku dipidana dengan pidana penjara seumur hidup atau pidana penjara paling singkat 5 (lima) tahun dan paling lama 20 (dua puluh) tahun dan pidana denda maksimum sebagaimana dimaksud pada ayat (1) ditambah $1 / 3$ (sepertiga).

Pasal 112

(1) Setiap orang yang tanpa hak atau melawan hukum memiliki, menyimpan, menguasai, atau menyediakan Narkotika Golongan I bukan tanaman, dipidana dengan pidana penjara paling singkat 4 (empat) tahun dan paling lama 12 (dua belas) tahun dan pidana denda paling sedikit Rp800.000.000,00 (delapan ratus juta rupiah) dan paling banyak Rp8.000.000.000,00 (delapan miliar rupiah).

(2) Dalam hal perbuatan memiliki, menyimpan, menguasai, atau menyediakan Narkotika Golongan I bukan tanaman sebagaimana dimaksud pada ayat (1) beratnya melebihi 5 (lima) gram, pelaku dipidana dengan pidana penjara seumur hidup atau pidana penjara paling singkat 5 (lima) tahun dan paling lama 20 (dua puluh) tahun dan pidanadenda maksimum sebagaimana dimaksud pada ayat (1) ditambah $1 / 3$ (sepertiga).

\section{Sudah diancam dengan}

hukuman pidana yang berat kepada pengedar, sindikat dan pemakai narkoba namun pelanggaran tidak pernah berhenti, mungkin karena perdagangan ini sangat menguntungkan atau subversi yang sangat berat. Penghancuran tanaman ganja terjadi di mana-mana namun masih dijumpai tanaman baru. Hal ini harus dihadapi bersama oleh seluruh lapisan masyarakat dengan aparataparat pemerintah dalam penumpasannya. Masyarakat harus cepat tanggap terhadap hal-hal yang sekiranya menjurus kearah kejahatan narkoba. Komunikasi harus dijalin sebaik-baiknya antara masyarakat dengan aparat-aparat pemerintah dalam mengadakan pemberantasan penyalahgunaan narkoba. (Romli, 2001)

Namun demikian bagi penyalahgunaan narkoba yang tujuan untuk memakai sendiri ini merupakan korban dari peredaran sendikaat narkoba yang harus dilindungi, apalagi pelaku penyalahgunaan pemakai narkoba kalangan generasi muda maka pemerintah dan masyarakat berkewajiban untuk memberikan pengobatan secara gratis sebagai di atur dalam Undang-Undang Nomor 35 Tahun 2009 tentang Narkotika sebagai berikut;

Pasal 53 
(1) Untuk kepentingan pengobatan dan berdasarkan indikasi medis, dokter dapat memberikan Narkotika Golongan II atau Golongan III dalam jumlah terbatas dan sediaan tertentu kepada pasien sesuai dengan ketentuan peraturan perundangundangan.

(2) Pasien sebagaimana dimaksud pada ayat (1) dapat memiliki, menyimpan, dan/atau membawa Narkotika untuk dirinya sendiri.

(3) Pasien sebagaimana dimaksud pada ayat (2) harus mempunyai bukti yang sah bahwa Narkotika yang dimiliki, disimpan, dan/atau dibawa untuk digunakandiperoleh secara sah sesuai dengan ketentuan peraturan perundang-undangan.

Pasal 54

Pecandu Narkotika dan korban penyalahgunaan Narkotika wajib menjalani rehabilitasi medis dan rehabilitasi sosial.

Pasal 55

(1) Orang tua atau wali dari Pecandu Narkotika yang belum cukup umur wajib melaporkan kepada pusat kesehatan masyarakat, rumah sakit, dan/atau lembaga rehabilitasi medis dan rehabilitasi sosial yang ditunjuk oleh Pemerintah untuk mendapatkan pengobatan dan/atauperawatan melalui rehabilitasi medis dan rehabilitasi sosial.

(2) Pecandu Narkotika yang sudah cukup umur wajib melaporkan diri atau dilaporkan oleh keluarganya kepada pusat kesehatan masyarakat, rumah sakit, dan/atau lembaga rehabilitasi medis dan rehabilitasi sosial yangditunjuk oleh Pemerintah untuk mendapatkan pengobatan dan/atau perawatan melalui rehabilitasimedis dan rehabilitasi sosial.

Apabila masyarakat dan keluarga korban penyalahgunaan narkoba sebagai pemakai ataupun sebagai pecandu narkoba berkewajiban melaporkan kepada pihak yang berwajib untuk dilakukan pengobatan dan rehabilitasi pada korban merupakan upaya yang harus segera dilakukan bila individu secara positif sudah memberikan tandatanda kecanduan narkotika/obat keras.

Disadari bahwa "penyakit" yang ditimbulkan karena kecanduan narkotika ini mempunyai permasalahan sendiri dan berbeda dengan penyakit lainnya. Karena rumit dan kompleksnya masalah ini, yang menyangkut aspek organobiologi, sosial cultural, pengibatan terhadap ketergantungan narkotika dan obat keras ini sangat sulit. Meskipun demikian upaya kea rah pengobatan korban ketergantungan narkotika/psikotropika harus dengan cepat dilaksanakan. Dalam pengobatan tidak hanya persoalan deteksifikasi serta pengawasan saja, 
perlu pula disertai evaluasi serta bimbingan psikiatrik yang kontinyu, walaupun penderita sudah kembali ke masyarakat, serta diperlukan juga partisipasi serta pengertian maupun penerimaan masyarakat untuk membantu penderita menjalani kehidupan yang wajar.

Untuk penderita yang akut perlu diadakan di tempat-tempat pengobatan yang mempunyai saranasarana perawatan (intensive unit cart). Dalam keadaan kritis tindakantindakan harus segera diberikan sebelum penderita mendapat perawatan dokter yang intensif.(Waresniwiro, 2004) Maka Pemerintah telah menyediakan Fasilitas dan Rumah Sakit tempat Rehabilitasi korban penyalahgunaan Narkoba sebanyak 16 Rumah Sakit di seluruh Indonesia untuk memberikan jaminan kesehatan bagi korban penyalahgunaan Narkoba.

Wakil Presiden Ma'ruf Amin menyatakan, Ini perlu segera di atasi penyalahgunaan Narkoba saat mengikuti puncak perayaan Hari Anti Narkotika Internasional (HANI) secara virtual, Jumat (26/6/2020). Gelaran tersebut bertajuk "Hidup $100 \%$ di Era New Normal Sadar, Sehat, Produktif dan Bahagia Tanpa
Narkoba." peringatan__ Hani penting untuk dilakukan sebagai momentum untuk tetap menunjukkan kewaspadaan terhadap bahaya narkotika. Apalagi, angka penyalahgunaan narkoba meningkat pada 2019. "Data BNN menyebutkan bahwa angka penyalahgunaan narkoba di Indonesia tahun 2017 sebanyak 3,37 juta jiwa dengan rentang usia 10-59 tahun. Tahun 2019 naik menjadi 3,6 juta," Sedangkan penyalahgunaan narkoba di kalangan pelajar di 2018 mencapai angka 2,29 juta. Adapun kelompok masyarakat yang paling rawan terpapar barang haram ini adalah mereka yang berada pada rentang usia 15-35 tahun atau generasi milenial. "Hal ini memerlukan perhatian khusus," pada tataran global, lembaga PBB yang mengurusi masalah narkotika, pada 2018 menyebutkan sebanyak 275 juta penduduk di dunia atau 5,6\% dari penduduk dunia (usia 15-64 tahun) pernah mengonsumsi narkoba.

Dengan demikian Pemerintah bersama masyarakat, perlu melakukan pencegahan dan penegakan Hukum untuk melindungi dan menjamin keselamatan jiwa serta kelanjutan terjaganya kesehatan generasi muda yang akan datang. 
Maka penegakan Hukum harus dilaksanakan secara tegas sebagai di atur dalam Undang-Undang Nomor 35 Tahun 2009 tentang Narkotika sebagai berikut;

Pasal 111

(1) Setiap orang yang tanpa hak atau melawan hukum menanam, memelihara, memiliki, menyimpan, menguasai,atau menyediakan Narkotika Golongan I dalam bentuk tanaman, dipidana dengan pidana penjara paling singkat 4 (empat) tahun dan paling lama 12 (dua belas) tahun dan pidana denda paling sedikit Rp800.000.000,00 (delapan ratus juta rupiah) dan paling banyak Rp8.000.000.000,00 (delapan miliar rupiah).

(2) Dalam hal perbuatan menanam, memelihara, memiliki,menyimpan, menguasai, atau menyediakan Narkotika Golongan I dalam bentuk tanaman sebagaimana dimaksud pada ayat (1) beratnya melebihi 1 (satu) kilogram atau melebihi 5 (lima) batang pohon, pelaku dipidana dengan pidana penjara seumur hidup atau pidana penjara paling singkat 5 (lima) tahun dan paling lama 20 (dua puluh) tahun dan pidana denda maksimum sebagaimana dimaksud pada ayat (1) ditambah $1 / 3$ (sepertiga).

Pasal 112

(1) Setiap orang yang tanpa hak atau melawan hukum memiliki, menyimpan, menguasai, atau menyediakan Narkotika Golongan I bukan tanaman, dipidana denganpidana penjara paling singkat 4 (empat) tahun dan palinglama 12 (dua belas) tahun dan pidana denda paling sedikit Rp800.000.000,00 (delapan ratus juta rupiah) dan palingbanyak

Rp8.000.000.000,00 (delapan miliar rupiah).

(2) Dalam hal perbuatan memiliki, menyimpan, menguasai, atau menyediakan Narkotika Golongan I bukan tanamansebagaimana dimaksud pada ayat (1) beratnya melebihi 5(lima) gram, pelaku dipidana dengan pidana penjaraseumur hidup atau pidana penjara paling singkat 5 (lima) tahun dan paling lama 20 (dua puluh) tahun dan pidana denda maksimum sebagaimana dimaksud pada ayat (1) ditambah $1 / 3$ (sepertiga).

Penegakan Hukum secara
tegas sangatlah penting karena narkoba dari tahun ketahun semakin meningkat penyalahgunaan narkoba, karena Tindak pidana Narkotika tidak lagi dilakukan secara perseorangan, melainkan melibatkan banyak orang yang secara bersama - sama, bahkan merupakan satu sindikat yang terorganisasi dengan jaringan yang luas yang bekerja secara rapi dan sangat rahasia baik di tingkat nasional maupun internasional. Maka perlu dilakukan pencegahan secara efktif untuk mencegah adanya kecenderungan yang semakin meningkat baik secara kuantitatif maupun kualitatif dengan korban 
yang meluas, terutama di kalangan anak-anak, remaja, dan generasi muda pada umumnya.

Untuk melindungi masyarakat dari bahaya penyalahgunaan Narkotika dan mencegah serta memberantas peredaran gelap Narkotika, dalam Undang-Undang ini diatur juga mengenai Prekursor Narkotika karena Prekursor Narkotika merupakan zat atau bahan pemula atau bahan kimia yang dapat digunakan dalam pembuatan Narkotika. Untuk lebih mengefektifkan pencegahan dan pemberantasan penyalahgunaan dan peredaran gelap Narkotika dan Prekursor Narkotika, diatur mengenai penguatan kelembagaan yang sudah ada yaitu Badan Narkotika Nasional (BNN). BNN tersebut didasarkan pada Peraturan Presiden Nomor 83 Tahun 2007 tentang Badan Narkotika Nasional, Badan Narkotika Provinsi, dan Badan Narkotika Kabupaten/Kota. BNN tersebut merupakan lembaga non struktural yang berkedudukan di bawah dan bertanggung jawab langsung kepada Presiden, yang hanya mempunyai tugas dan fungsi melakukan koordinasi. karenanya BNN ditingkatkan menjadi lembaga pemerintah non kementerian (LPNK) dan diperkuat kewenangannya untuk melakukan penyelidikan dan penyidikan.

BNN berkedudukan di bawah Presiden dan bertanggung jawab kepada Presiden. Selain itu, BNN juga mempunyai perwakilan di daerah provinsi dan kabupaten/kota sebagai instansi vertikal, yakni BNN provinsi dan BNN kabupaten/kota. ${ }^{1}$

Ketentuan mengenai korporasi dan per-tanggungjawaban pidananya di atur dalam beberapa pasal sebagai berikut:2

a. Pasal 182:

"Korporasi adalah kumpulan terorganisasi dari orang dan/atau kekayaan, baik merupakan badan hukum maupun bukan badan hukum".

b. Pasal 47:

"Korporasi merupakan subyek tindak pidana".

c. Pasal 48:

"Tindak pidana dilakukan oleh korporasi apabila dilakukan oleh orang-orang yang bertindak untuk

\footnotetext{
1 . Penjelasan Undang-Undang Nomor 35 Tahun 2009 tentang Narkotika

2 Rancangan Konsep KUHP 2005, Departemen Hukum dan Hak Asasi Manusia Republik Indonesia, Dirjen Peraturan Perundang-Undangan, Jakarta : Juli 2005, hlm. 12-13
} 
dan atas nama korporasi atau demi kepentingan korporasi, berdasarkan hubungan kerja atau hubungan lain, dalam lingkup usaha korporasi tersebut, baik sendiri-sendiri atau bersamasama".

d. Pasal 49:

"Jika tindak pidana dilakukan oleh korporasi, pertanggungjawaban pidana dikenakan terhadap korporasi dan/atau pengurusnya".

e. Pasal 50:

“Korporasi dapat dipertanggungjawabkan secara pidana terhadap suatu perbuatan yang dilakukan untukdan/atau atas nama korporasi, jika perbuatan tersebut termasuk dalam lingkup usahanya sebagaimana ditentukan dalam anggaran dasar atau ketentuan lain yang berlaku bagi korporasi yang bersangkutan".

f. Pasal 51:

"pertanggungjawaban pidana pengurus korporasi dibatasi sepanjang pengurus mempunyai kedudukan fungsional dalam struktur organisasi korporasi”.

g. Pasal 52:

(1) Dalam mempertimbangkan suatu tuntutan pidana, harus dipertimbangkan apakah bagian hukum lain telah memberikan perlindungan yang lebih berguna daripada menjatuhkan pidana terhadap suatu korporasi.

(2) Pertimbangan sebagaimana dimaksud pada ayat (1) harus dinyatakan dalam putusan hakim.

h. Pasal 53:

"Alasan pemaaf dan alasan pembenar yang dapat diajukan oleh pembuat yang bertindak untu dan/atau atas nama korporasi, dapat diajukan oleh korporasi sepanjang alasan tersebut langsung berhubungan dengan perbuatan yang didakwakan kepada korporasi".

Dari perumusan konsep diatas terlihat pokok-pokok kebijakan yang diatur adalah :

a. Defenisi tentang korporasi dalam artian luas, baik sebagi badan hukum maupun bukan sebagai badan hukum (Pasal 182).

b. Penegasan korporasi sebagai subyek tindak pidana (Pasal 47).

c. Penentuan kapan korporasi dikatakan telah melakukan tindak pidana (Pasal 48).

d. Penentuan siapa yang dapat dipertanggungjawabkan (Pasal 49).

e. Penentuan kapan korporasi dapat dipertanggungjawabkan (Pasal $50)$. 
f. Penentuan kapan pengurus dapat dipertanggungjawabkan (Pasal 51).

g. Penentuan pidana sebagai ultimatum remedium bagi korporasi (Pasal 52).

h. Penentuan alasan pembenar dan pemaaf bagi korporasi (Pasal 53).

Dari kebijakan formulasi diatas, terlihat bahwa pertanggung jawaban pidana korporasi masih berorientasi pada orang dan belum berorientasi pada pemidanaan terhadap korporasi itu sendiri.

\section{E. PENUTUP}

\section{Kesimpulan}

Pasal 18 dan 19 UndangUndang Republik Indonesia Nomor 36 Tahun 2009 tentang Kesehatan, menyebutkan, bahwa Pemerintah bertanggung jawab memberdayakan dan mendorong peran aktif masyarakat dalam segala bentuk upaya kesehatan., dan Pemerintah bertanggung jawab atas ketersediaan segala bentuk upaya kesehatan yang bermutu, aman, efisien, dan terjangkau, maka Penegakan Hukum secara tegas sangatlah penting karena narkoba dari tahun ketahun semakin meningkat penyalahgunaan narkoba, karena Tindak pidana Narkotika tidak lagi dilakukan secara perseorangan, melainkan melibatkan banyak orang yang secara bersama - sama, bahkan merupakan satu sindikat yang terorganisasi dengan jaringan yang luas yang bekerja secara rapi dan sangat rahasia baik di tingkat nasional maupun internasional. Maka perlu dilakukan pencegahan secara efktif untuk mencegah adanya kecenderungan yang semakin meningkat baik secara kuantitatif maupun kualitatif dengan korban yang meluas, terutama di kalangan anak-anak, remaja, dan generasi muda pada umumnya sesuai UndangUndang Nomor 35 Tahun 2009 tentang Narkotika.

\section{Saran}

Generasi muda mempunyai peran penting sebagai salah satu penentu dan kemajuan suatu bangsa untuk tercapainya tujuan nasional, pemuda merupakan kekuatan moral, kontrol sosial, dan agen perubahan sebagai perwujudan dari fungsi, peran, karakteristik, dan kedudukannya yang strategis dalam kemajuan negara. Untuk itu, tanggung jawab dan peran strategis pemuda di segala dimensi pembangunan perlu ditingkatkan dan harus di lindungi 
dari Bahaya Narkotika Bagi Kesehatan Masa Depan Generasi Muda, maka peran aktif Pemerintah dalam pemberantasan narkoba sangat penting untuk menyelamatkan generasi muda yang akan datang sebagai Pelayanan kepemudaan adalah penyadaran, pemberdayaan, dan pengembangan kepemimpinan, kewirausahaan, serta kepeloporan pemuda. 5. Penyadaran pemuda adalah kegiatan yang diarahkan untuk memahami dan menyikapi perubahan lingkungan sesuai Undang-Undang Nomor 40 Tahun 2009 tentang Kepemudaan

\section{DAFTAR PUSTAKA}

B.A Sitanggang, 1999, Pendidikan Pencegahan Penyalahgunaan Narkotika, Jakarta: Karya Utama.

Willy, H. 2005, Berantas Narkoba, Tak Cukup Hanya Bicara (Tanya Jawab), Yogyakarta, Kedaulatan Rakyat.

Ibrahim, J. 2006, Teori \& Metodologi Penelitian Hukum Normatif, Malang: Bayumedia Publishing.

Kamus Besar Bahasa Indonesia. 2008, Jakarta: Balai Pustaka.

Kontjaraningrat, 1997 MetodeMetode Penelitian Masyarakat, Jakarta : PT. Gramedia.

M. Waresniwiro, (2004), Narkotika Berbahaya, Jakarta, Mitra Bintibmas.
Fitri. M dan Migunani, S. 2014. Sosialisasi dan Penyeluhan Narkoba' Jurnal Inovasi dan Kewirausahaan. Volume 3 No. 2 Mei 2014.

Hartono, S. 1994 "Penelitian Hukum di Idonesia Pada Akhir Abad ke20", Bandung: Alumni.

Soekanto. S. \& Mamudji, S. 2007,"Penelitian Hukum Normati Suatu Tingjauan Singkat", Jakarta; PT. Raja Grafindo Persada.

Naafs. S. \& White, B. 2012, Generasi Antara: Refleksi tentang Studi Pemuda Indonesia , JURNAL STUDI PEMUDA. VOL. I NO. 2 SEPTEMBER 2012.

Atmasamita, R. 2001, Tindak Pidana Narkotika Trans Nasional Dalam Sistem Hukum Indonesia, Bandung, Citra Aditya Bakti,

Harirah MS, Z. Drs H. Isril, 2015, Role Model Kebijakan Pemberantasan Penyalahgunaan Narkotika di Kota Pekan Baru, JOM FISIP Vol 2 No 1 Februari 2015.

Tim Ganeca Sains, 2001. "Bandung Kamus lengkap Bahasa Indonesia, (Bandung: Penabur Ilmu.

Peran Politik Pemuda, (2009), Dinamika Pergerakan Pemuda Sejak Sumpah Pemuda 1928 Sampai Kini Jurnal DEBAT Edisi Pertama, Agustus 2009.

Wulandari, S. 2011. "Identifikasi Bahaya, Penilaian, dan Pengendalian Risiko Area Produksi Line 3 sebagai Upaya Pencegahan Kecelakaan Kerja di PT. Coca Cola Amatil Indonesia Central Java" (Tugas Akhir D.III Hiperkes dan Keselamatan Kerja Fakultas Kedokteran UNS Surakarta, 2011).

Fahriani, di kutip tgl 25 Agustus 2020, hal.8.ttps://www.google.com/s earch?safe=strict\&ei 
Hamzah, H. $1996 . \quad$ Azas Pertanggungan Korporasi dalam Hukum Pidana (Strict Liability dan Vocrious Liability), Jakarta: Raja Garfindo Persada.

Luqman, L. tt. Kapita Selekta Tindak Pidana Di Bidang Perekonomian, Jakarta: Datacom, (tanpa tahun)

Muladi, Prinsip-Prinsip Dasar Hukum Pidana Lingkungan Dalam Kaitannya dengan UU No.23 Tahun 1997, Bandung: Jurnal Hukum Pidana dan Kriminologi, Volume I/Nomor 1/ 1998

Priyatno, D. 2004. Kebijakan Legislasi Tentang Sistem Pertanggungjawaban Pidana Korporasi Di Indonesia, Bandung: CV. Utomo.

Rancangan Konsep KUHP 2005, Departemen Hukum dan Hak Asasi Manusia Republik Indonesia, Dirjen Peraturan Perundang-Undangan, Jakarta: Juli 2005

Mardjono, R. 1994. Kemajuan Pembangunan Ekonomi dan Kejahatan, Jakarta: Pusat Pelayanan Keadilan dan Pengabdian Hukum UI.

Sudarto, 1981. Kapita Selekta Hukum Pidana, Bandung: Alumni. 